\title{
Review on Honey Value Chain in Ethiopia
}

\author{
Siyoum Yifru Feyissa \\ Technology Transfer and Consultancy Service Team Leader, \\ Ethiopian Meat and Dairy Industry Development Institute, Bishoftu, Ethiopia
}

\begin{abstract}
The review has been conducted with the objectives of the core functions and major actors involved, distribution of benefits of actors along the honey value chain and Challenges and opportunities of honey value chain in Ethiopia. Ethiopia is home to some of the most diverse flora and fauna in Africa. The country produced about 45 thousand tons which accounted about $27 \%$ and $3 \%$ of African and World honey production respectively and makes the country the largest producers in Africa and the tenth in the world. More than one million households are estimated to keep bees using traditional, intermediate and modern hives. Apiculture is a promising off-farm enterprise, which directly and indirectly contributes to smallholder's income in particular and nation's economy in general. It has been reported that annually an average of 420 million Ethiopian Birr is obtained from the sale of honey. The subsector is also creating job opportunities in both rural and urban areas through organizing jobless urban and landless rural youth and women to involve in them in bee equipment production and beekeeping activities. The sector traditional production system is the main feature where $96 \%$ of the hives are reported to be traditional and $91 \%$ of the total honey produced comes from traditional hives. Ethiopia has adequate natural resources and a long tradition and culture of beekeeping. However, mainly because of lack of technological changes, institutional supports and access to market and value chain development, the country in general and the rural beekeeping households in particular have not been sufficiently benefited from the sub sector. The major constraints to exploit the untapped potential of beekeeping activity in the country are lack of knowledge and skill on beekeeping, lack of institutional linkage, lack of organized marketing channel, low access to improved beekeeping equipment and agrochemical bee poisoning. Efforts should be geared to develop efficient input delivery systems and knowledge-based honey production to improve production side and introduction of value adding management practices and market linkage from marketing side are the most important aspect of enhancing the livelihood and source of income for honey producers.
\end{abstract}

Keywords: Honey; Value chain; Market channel; Challenges; Ethiopia

DOI: $10.7176 / \mathrm{JMCR} / 84-01$

Publication date: January $31^{\text {st }} 2022$

\section{Introduction}

1.1. Background

Ethiopia is gifted with diverse ecological and climatic condition. It is also home to some of the most diverse flora and fauna in Africa (Allafrica.com, 2009). It is among the major producer of honey both in Africa and in the world. For instance, in 2013 the country produced about 45 thousand tons which accounted about $27 \%$ and $3 \%$ of African and World honey production respectively and makes the country the largest producers in Africa and the tenth in the world (FAO, 2013). Its forests and woodlands contain diverse plant species that provide surplus nectar and pollen to foraging bees (Addis, 2016).

More than one million households are estimated to keep bees using traditional, intermediate and modern hives Gidey and Mekonen (2010). In the country more than ten types of traditional hives are used with an average honey yield of 5 to $8 \mathrm{~kg}$ per colony per year. The variation of hives is based on their volumes, shapes and the type of materials used for construction. Production is dependent on forest resources and Ethiopia's diverse sources of bee forage (FAO, 2010).

Apiculture is a promising off-farm enterprise, which directly and indirectly contributes to smallholder's income in particular and nation's economy in general (Chala, 2013). It has been reported that annually an average of 420 million Ethiopian Birr is obtained from the sale of honey (MoA and ILRI, 2013).

The subsector is also creating job opportunities in both rural and urban areas through organizing jobless urban and landless rural youth and women to involve them in bee equipment production and beekeeping activities (Workneh, 2011).

Despite the long tradition of beekeeping in Ethiopia, being the leading honey producer, the availability of huge potential and the attention given to the sector traditional production system is the main feature where $96 \%$ of the hives are reported to be traditional and $91 \%$ of the total honey produced come from traditional hives (CSA, 2015). Proper understanding of the production and market system apparently required for making market orientation of honey production (Gemechis, 2015)

In Ethiopia agricultural value chains are weak and its agri-processing for value addition is very limited. Besides that, poor producer organization and lack of strong value chain financing system capped the agricultural 
sector (Coates et al., 2011). Honey value chain played a significant role in the economy of the country by engaging around two million farm households (USAID, AGP-AMDe, 2012). It also engaged different actors participated in different value adding activities which enables them to higher the value of product and increases their bargaining power.

However, these actors and their function are not literally identified. In a given value chain, financial service is an important instrument to improve the welfare of a poor through enhancing their productive capacity (Okurut et al., 2004) and it also motivates them to participate in further value adding activities rather than directly sell the product in order to meet their current financial need.

Despite its importance to small scale producers to participate in a value adding activities, its supply for improved apiculture is limited in Ethiopia (ILRI, 2011).

\subsection{Objective of the Review}

\subsubsection{General objective}

- To review honey value chain in Ethiopia.

1.2.2. Specific objectives

- to review the core functions, major actors involved and distribution of benefits of actors along the honey value chain and

- to review Challenges and opportunities of honey value chain in Ethiopia

\section{Honey Value Chain in Ethiopia}

\subsubsection{Value chain concepts}

The value chain concept can be divided into two main streams of literature. The one is based on porter's value chain model and other is known as Global Value Chains (Gerefti \& Korzeniewicf, 1994). The concept of value was incorporated into the framework when researchers started to use the analysis to show where value is captured within a particular industry (Gerefti \& Christian, 2010).

Porter (2004) claims that value chain analysis is a basic tool for diagnosis competitive advantages and finding ways to create and sustain it over it. KIT et al. (2006) defines value chains as set linkages between actors who seek to support each other with the objective of increasing effectiveness and competitiveness. According to Roduner (2007) value chains analyses the links and information flows within the chain and reveals the strengths and weaknesses in the process. It also analyses the boundaries between national and international chains, takes into consideration buyers' requirements and international standards.

Honey value chain in Ethiopia

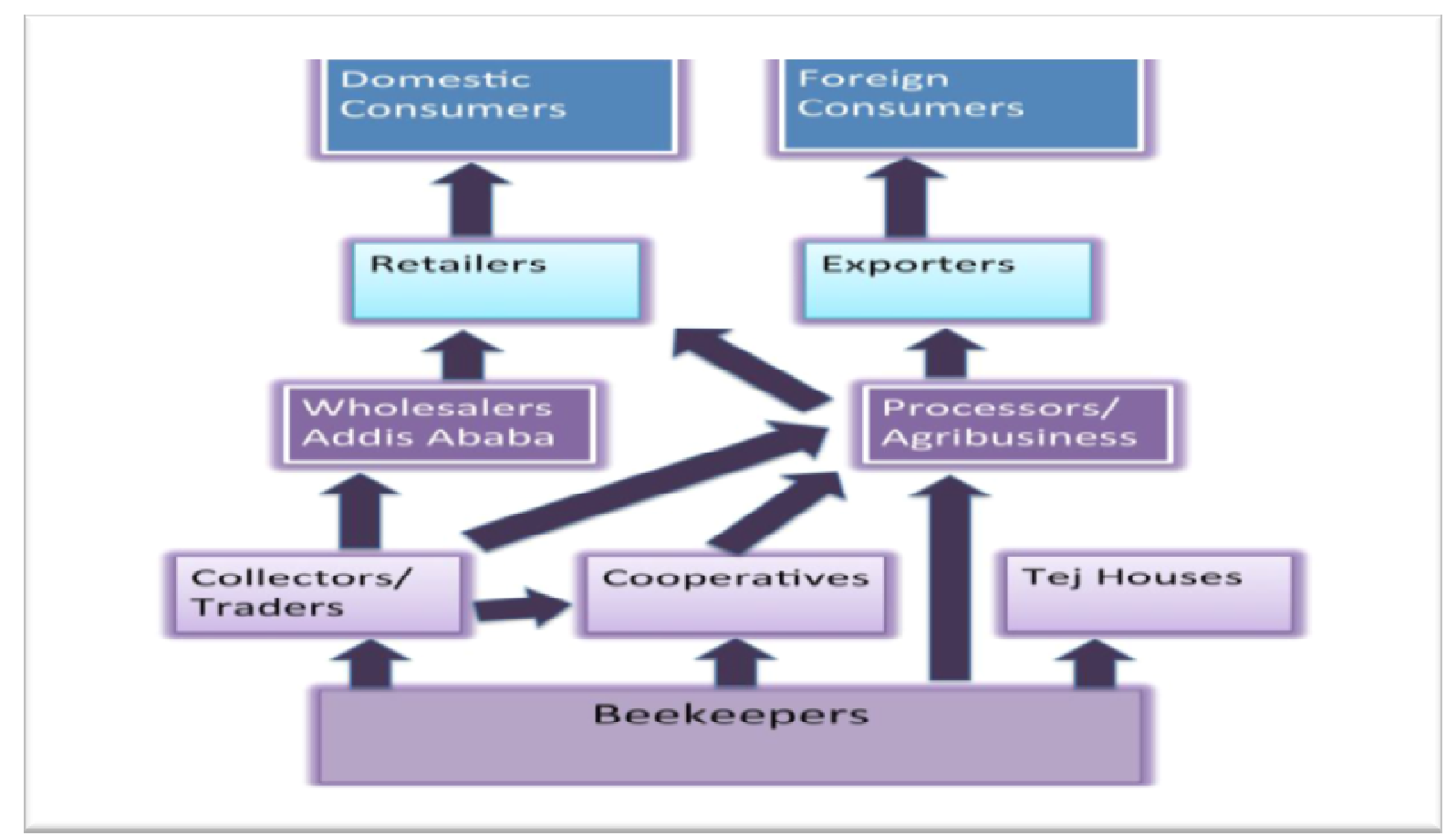

Figure 1: Map of Honey Value Chain in Ethiopia Source: Mikhail et al. (2013) 


\subsection{Value chain Analysis}

A variety of approaches used in conducting a value chain analysis. First; one must understand the different actors in an input and output in the value chain. After understanding the different actors one is able to identify the different tools to use for different factors such as producers and trader surveys. According to (GTZ, 2007), value chain map shows the flow of product and services among the major actors from early supply of inputs and production up to consumption. It summarizes major value chain actors, enterprises (input suppliers) and value chain supporters. The value chain also illustrates the different market channels that a product takes before reaching the final consumer Betselot (2012).Therefore a value chain is an important tool to use for identifying bottlenecks, as well as possible opportunities that may not be apparent otherwise.

\subsection{Major honey value chain actors}

Producers: are the major actors who perform most of the value chain functions from the procurement of the inputs to harvesting and marketing. The major value chain functions that honey producers perform include sorting, filtering, packaging and transporting (Kassa et al., 2018).

Collectors: These are farmer traders who collects honey at a farm get level from the producers and sell it to the wholesalers and retailers in the district market.

Wholesalers: These actors buy honey either from collectors or producers at a large quantity and resell to other traders in a bulk.

Retailers: These are key actors in honey value chain. They connect the wholesalers and urban consumers by offering according to the requirements and purchasing power of the buyers.

Processors: These are retailers both in urban and rural areas who purchase crude honey from wholesalers and supply honey to consumers in the form of brewery, locally known as tej.

Cooperatives: These are the major actors who directly participate in marketing of honey and also support honey producers. These actors organize honey producing households to make them to regularly supply filtered honey that is to be sold for consumers. Cooperatives are jointly working with households and supply a filtering machine for honey producing households. They also give trainings on how to use it and supply quality honey to them.

Consumers: these are the final actors of the chain who buy the product for their own consumption purpose.

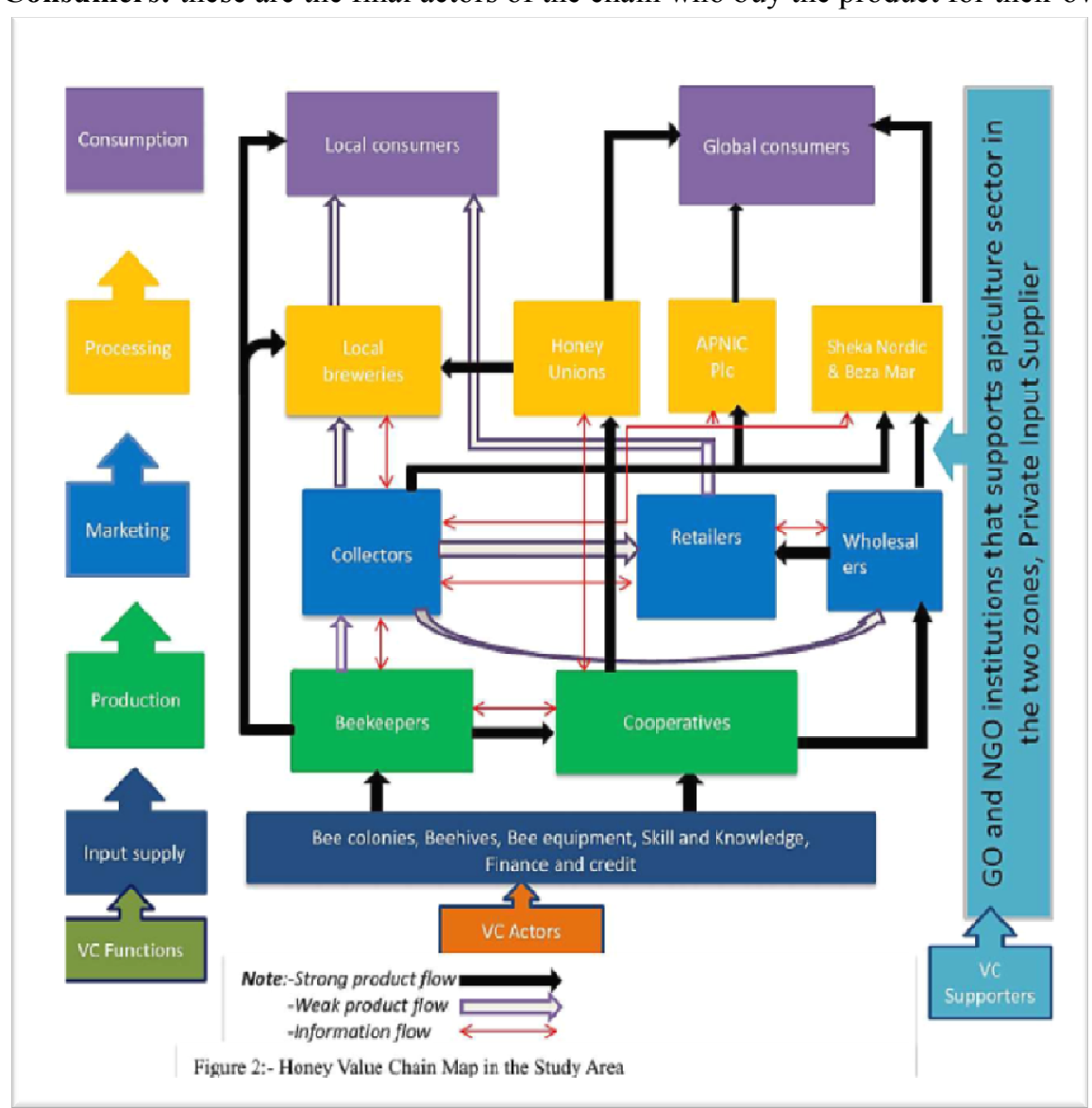

Figure 2: Mapping of Honey Value Chain Actors, Supporters and their Functions Source: Kassa et al. (2018) 


\subsection{Value chain supporters}

Honey value chain is supported by different actors who facilitate the performance of major actors. Woreda Agricultural and Development Office (WADO), and NGOs are supply protective wear and modern bee hives for the households as a long term loan though $77 \%$ of the sampled household perceives as it is not sufficient. These actors also provide trainings on how to make locally made transitional hive known as chefeka. Cash credit supply is also one of the major supporting activities of the chain. The survey result shows that $50.8 \%$ of the sampled honey producing households were formal credit users and out of them $95.9 \%$ get it from Omo Micro Finance Institution (Biruk et al., 2018).

\subsection{Value adding activities of producers}

Transportation is one of the major value adding activities undertaken by producer. Out of the total produced honey, $98.3 \%$ will be sold and while the remaining $1.7 \%$ only for the household consumption. Out of the total market participant households, $50.8 \%$ sold their entire product by supplying it to different markets while others sold it both in farm and market. The households use different transporting means such as car, cart and donkey to supply the product to the market (Biruk et al., 2018).

Sorting and packing: Packing instrument is an indispensable thing to keep the product from spoilage and keep the product quality. The producers, who supply their product to the market, pack their product with different materials especially with clay pot, sack and plastic box. Out of the total sampled $1.7 \%, 87.2 \%$ and $9.4 \%$ pack their product with plastic sack, plastic box and clay pot, respectively while the remaining were sold their product at home. $70.8 \%$ of the sampled households sort and grade their product based on the color of their product as white or black and sell the white honey at a higher price than the black.

Filtering: The establishment of cooperatives initiated honey filtration activities in the study area and enabled the producers to get higher value. Out of the total sampled households, 38.3\% filtered their product both manually and or by machine before they supply their product to the market and of these $23.7 \%, 73.7 \%$ and $2.6 \%$ filtered their product manually, by machine and both, respectively.

Processing: This is one of value adding activities in the honey value chain which is undertaken by brewers locally known as tej makers. In this case, the actors use the crude honey to make tej and supply to the consumers.

\subsection{Challenges and opportunities of honey value chain}

2.6.1. Opportunities

Market: According to the study of Tezera (2013), there is a highly growing demand of honey in Ethiopia. The study area has also export demand though it is delayed due to lack of regular supply of the product throughout the year.

Establishment of Ministry of Livestock Development and Fisheries: Launching of competent authority as a separate ministry will provide substantial benefit on identification and solving of sector challenges. It will also ensure apiculture development by strengthening extension delivery system for small scale households.

Current government policy towards apiculture: Establishment of favorable policy environment for the apiculture sector under the Agricultural Growth and Transformation Plan (GTP) (MoFED 2010) like proclamation 660/2009 will provide different opportunities for the sector if able to extract it. The government is also working with a vision of exporting approximately 2400 tons by 2025 whose current export is approximately only 400 tons (Demisew, 2016) through increasing the production and productivity level.

2.6.2. Challenges

Shortage of input supply: Lack of adequate access to basic inputs influenced the productivity and quality of the product. Especially, unavailability of different sized packing instruments influenced to use sacks and oil plastic box that affect the quality of honey. Even if filtered honey is sold at a higher price, only $38.3 \%$ of the producer honey was filtered by the households (Biruk et al., 2018).

Lack of skill to make locally made transitional hive: Modern and transitional hives use is one of the way to maximize the productivity of honey. Locally produced transitional hive, is also one of them. The ability to be produced from local inputs by any farmer makes it easily accessible. But, the study area has skill gap to construct it. $50.9 \%$ of the total sampled households did not use traditional hive and even the remaining $44.8 \%$ also uses less than 5 hives.

Lack of Knowledge and Skill on Beekeeping: beekeepers have been engaged in the sector for long years knowledge of how to keep them well and get better pay back is very low which results in lack of proper management of the beehives. Some of the problems observed were poor/no shades for hives, poor sanitation in the process of production, harvesting, storing and transporting of honey.

Shortage of bee forage: Shortage of bee forage in dry season led to lose bees in dry season which hinders the successive supply of product. $75 \%$ of the sampled households consider it as a challenge not to produce subsequent quantity of honey throughout the year and they perceive it as a cause for a loss of bee colonies. 
Table 1: Challenges of honey value chain along the chain actors

\begin{tabular}{|c|c|c|}
\hline s/no & Actors & Challenges \\
\hline 1 & Producers & $\begin{array}{ll}\text { - } & \text { Low access to input } \\
\text { - } & \text { Lack of packaging materials } \\
\text { - } & \text { Lack of skill to make locally made transitional hive } \\
\text { - } & \text { Chemical poison problem due to crop herbicide and pest spray } \\
\text { - } & \text { Financial limitation }\end{array}$ \\
\hline 2 & cooperatives & $\begin{array}{l}\text { - Low support from the government side for strengthen the honey cooperatives } \\
\text { - } \quad \text { Finance limitation } \\
\text { - } \quad \text { Low organizational and institutional development }\end{array}$ \\
\hline 3 & Wholesalers & - $\quad$ Lack of well-developed infrastructure facilities \\
\hline 4 & Processors & $\begin{array}{ll}\text { - } & \text { Technological problem } \\
\text { - } & \text { Low quality of raw materials(honey) } \\
\text { - } & \text { Low skill of processing } \\
\text { - } & \text { Adulteration problem } \\
\end{array}$ \\
\hline 5 & Retailers & $\begin{array}{ll}\text { - } & \text { Low quality } \\
\text { - } & \text { Finance limitation } \\
\text { - } & \text { Lack of packaging materials } \\
\text { - } & \text { Technological problem } \\
\text { - } & \text { Retailing shop and cooling materials problem }\end{array}$ \\
\hline 6 & Consumers & $\begin{array}{ll}- & \text { High price } \\
\text { - } & \text { Low quality } \\
\text { - } & \text { Low availability }\end{array}$ \\
\hline
\end{tabular}

\subsection{Honey marketing channels}

According to the quantity of honey that passes through the actors, the study area has 6 main channels in which $11510 \mathrm{~kg}$ of honey flows to reach the final actors (consumers).

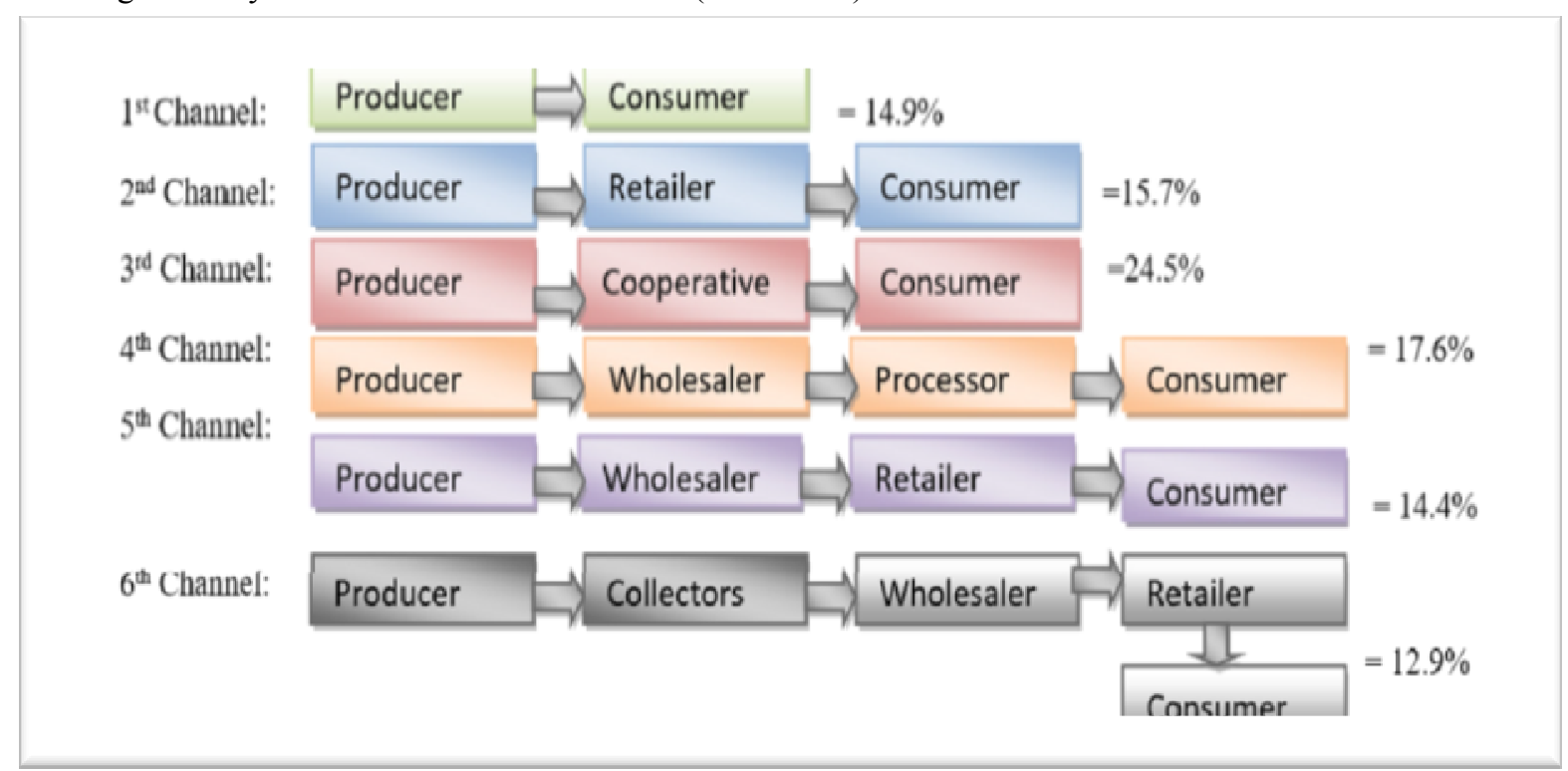

Figure 3: Map of Honey marketing channels

Source: (Biruk et al., 2018). 


\begin{tabular}{|c|c|c|c|c|c|c|c|c|}
\hline \multirow[t]{3}{*}{ Decision } & \multicolumn{8}{|c|}{ Honey marketing outlets } \\
\hline & \multicolumn{2}{|l|}{ Retailers } & \multicolumn{2}{|c|}{ Cooperatives } & \multicolumn{2}{|l|}{ Collectors } & \multicolumn{2}{|l|}{ Consumers } \\
\hline & Frequency & $\%$ & Frequency & $\%$ & Frequency & $\%$ & Frequency & $\%$ \\
\hline Yes & 106 & 68.83 & 113 & 73.37 & 95 & 61.69 & 72 & 46.75 \\
\hline № & 48 & 31.17 & 41 & 26.63 & 59 & 38.31 & 82 & 53.25 \\
\hline \multirow[t]{2}{*}{ Supply to each outlet } & Mean & SD & Mean & SD & Mean & SD & Mean & SD \\
\hline & 47.94 & 21.46 & 87.09 & 30.40 & 60.18 & 26.87 & 33.9 & 15.78 \\
\hline
\end{tabular}

Figure 4: Description of Honey marketing channels

Source: (Kassa et al., 2017)

Accordingly, to Kassa et al.(2017) result; different honey market outlets were used to sale honey produced. These honey market outlets include retailers, cooperatives, collectors, and consumers. One of the most commonly used market outlets by producers is the cooperative outlet which was chosen by about $73.37 \%$ respondents with mean supply of $87.1 \mathrm{~kg}$, while about $68.83 \%$ of respondents sold to retailers with mean supply of $47.94 \mathrm{~kg}$. Collectors are also a common honey marketing outlet which is around 61.69\% of sample households sold to the collectors with mean supply of $60 \mathrm{~kg}$. From the total sampled households, $46.75 \%$ of them choose consumers as honey marketing outlet with mean supply of $15.78 \mathrm{~kg}$.

\subsection{Honey Value Chain Financing}

Lack of strong internal value chain financing system challenged the effectiveness of honey value chain. Producers, in honey value chain, may meet their financial need either from self-production or loans and credits. Loans and credits of a given value chain may flow either when the financing institutions finance one end of the value chain and then it channels to the other links or they can finance producers directly(Biruk et al., 2018).

2.8.1. External producers' finance providers

Omo Micro Finance: It is a major loan supplying institution for sampled households. It provides cash credit to honey producers with a maximum of one year term loan. The average loan size was ETB 1419 with a minimum and maximum of ETB1000 and 8,000 respectively.

Woreda Agricultural and Development Office (WADO) and NGOs: These institutions supply in kind credit both in long term and short-term loan. They mostly supply protective wear and modern bee hives for model honey producing households.

2.8.2. Internal producers' finance providers:

Cooperatives supply in kind credit to the producers like filtering machine. It supplies one filtering machine for forty selected honey producing households in model kebeles.

Self-supply: This is a financing system by which the business finances itself back. In this case, farmers spent the income generated from apiculture for purchasing inputs or further expansion.

2.8.3. Challenges of producers financing

$65 \%$ of the sampled households are remark that there is shortage of input supply especially bee hives and protective wear, and the data shows that only $20 \%$ of the sample accessed both protective wear and bee hives as a loan. Therefore, access to these inputs need to be explicitly accounted for in the design of policies and programs. Lack of strong internal value chain financing system and mutual benefiting agreements between producers and other major value chain actors is affected the efficiency of value chain except for cooperatives.

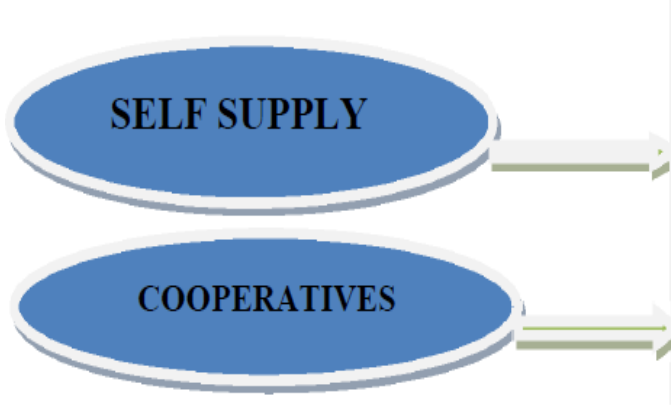

Internal value chain financers

Figure 5: Map of Producer Financing

Source: (Biruk et al., 2018)
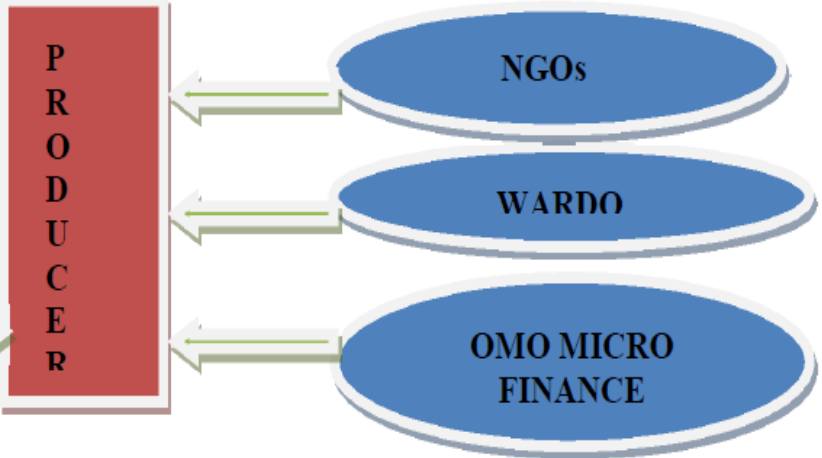

External value chain financers 


\subsection{Honey marketing margins}

The result of marketing margin analysis showed that the highest percentage was found for channel six followed by channel four i.e. $54.79 \%$ and $45 \%$ respectively. Regarding the producers' portion which is the portion of the price paid by the end consumer that goes to the producers, channel threes' marketing margin that passes through cooperatives was found the highest total gross marketing margin $90.67 \%$ next to the channel that passes directly from producers to consumers this is because the producers add more value than other channels.

Table 2: Honey marketing margin for different channels

\begin{tabular}{|c|c|c|c|c|c|c|c|c|}
\hline \multirow{2}{*}{ I } & \multirow[t]{2}{*}{ Actors } & & \multicolumn{6}{|c|}{ Honey market channels } \\
\hline & & & $\mathrm{I}$ & II & III & IV & $\mathrm{V}$ & VI \\
\hline I & Producer & Selling price & 65 & 45 & 68 & 36 & 47 & 32 \\
\hline I & & GMMp (\%) & 100 & 75 & 90.67 & 55 & 77.12 & 45.21 \\
\hline 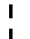 & Wholesaler & Purchase price & & & & 36 & 47 & 47 \\
\hline I & & Selling price & & & & 45 & 55 & 55 \\
\hline I & & GMMw(\%) & & & & 20 & 14.55 & 14.55 \\
\hline I & & & & & & & & \\
\hline I & Retailer & Purchase price & & 45 & & & 55 & 55 \\
\hline I & & Selling price & & 60 & & & 60 & $\begin{array}{l}60 \\
833\end{array}$ \\
\hline i & & & & & & & 8.33 & 8.33 \\
\hline i & Processor & Purchase price & & & & 45 & & \\
\hline I & & Selling price & & & & 60 & & \\
\hline I & & GMMp $(\%)$ & & & & 25 & & \\
\hline I & & & & & & & & \\
\hline I & cooperatives & Purchase price & & & 68 & & & \\
\hline I & & Selling price & & & 75 & & & \\
\hline I & & GMMcp (\%) & & & 9.33 & & & \\
\hline I & & & & & & & & \\
\hline i & Collectors & Purchase price & & & & & & 32 \\
\hline i & & Selling price & & & & & & 47 \\
\hline i & & GMMcl $(\%)$ & 100 & 25 & 9.33 & 45 & 22.88 & 31.91 \\
\hline I & & TGGM $(\%)$ & & & & & & 54.79 \\
\hline
\end{tabular}

Source: (Biruk et al., 2018)

\section{Conclusions and Recommendations}

\subsection{Conclusions}

Ethiopia has adequate natural resources and a long tradition and culture of beekeeping. However, mainly because of lack of technological changes, institutional supports and access to market and value chain development; the country in general and the rural beekeeping households in particular have not been sufficiently benefited from the sub sector. Yet, despite all the constraints and challenges currently facing the beekeeping subsectors are still enormous opportunities and potentials to boost the production and marketing of products in Ethiopia.

The major constraints to exploit the untapped potential of beekeeping activity in the country are lack of knowledge and skill on beekeeping, lack of institutional linkage, lack of organized marketing channel, low access to improved beekeeping equipment and agro-chemical bee poisoning. Majority of the beekeepers follow traditional colony management, harvesting and processing methods to produce honey. Lack of strong internal value chain financing system challenged the effectiveness of honey value chain.

\subsection{Recommendations}

After reviewing different findings, it might be appropriate to consider the following; research, development and policy issues in order to make improvement interventions for the development of honey value chain in Ethiopia.

\section{Research issues:}

$>$ Testing and using technologies to speed up production improvement of honey

$>$ Developing honey processing and preservation technologies appropriate to the various major agroecological zones of the country.

Promoting HACCP program at farm-level to assure honey quality and safety.

\section{Development issues:}

$>$ Training for smallholder farmers on modern bee management practices.

$>$ Encouraging and supporting an efficient and operational public and private apiculture extension and advisory service provision such as: honey input provision, technology transfer and producer-researchprivate sector linkage.

$>$ Strengthen existing honey cooperatives and promote to establishment new honey cooperative throughout the country.

$>$ There should be mutual understanding between crop producers and honey producers to reduce chemical poisonous of the bees. At the time of any chemical application to the crops the farmers should have 
information and keep the bees at protected place which made of mish wire based on the severity and time allocated for the applied chemical.

$>$ Strengthen internal value chain financing system and rural credit through microfinance institutions to increase the effectiveness of honey value chain.

\section{Policy issues}

$>$ The policies should establish an appropriate marketing infrastructure to ensure honey collection, processing, storage, and distribution, the quality of products.

$>$ A functional payment system based on quality should be implemented. The introduction of this system of payment in other countries showed an improvement in both quality and quantity produced and supplied to honey collection centers.

$>$ The pricing should aim at motivating honey producers to increase their efforts in hygienic honey collection practices and handling.

$>$ The need to strengthening existing established apiculture advisory services at national level is important to make improvements on the various components of the honey value chain.

\section{References}

Addis, N. M. (2016). Value Chain Analysis of Honey: in the case of Basona Worena Woreda, Smien Shewa, Zone Amhara rigion, Ethiopia.

Allafrica.com. (2009). Ethiopia: land of wax and honey, April, 2009, (http:// allafrica.com /stories/ 200904170706.html)

Betselot, M. (2012). Honey value Chain Analysis with Especial Emphasis to Ada'a woreda, east Shoa Zone of Ethiopia :(M.Sc. Thesis presented to School of Graduate Studies of Haramaya University), Haramaya, Ethiopia.

Biruk, J., Endrias, G. and Lemma, Z. (2018). Honey Value Chain Analysis and Producers Financing in Damot Gale District, Southern Ethiopia: Hawassa University, Wondo Genet College of Forestry and Natural Resources Southern Agricultural Research Institute (SARI) Haramaya University, Food Science and Quality Management, SSN 2224-6088 ISSN 2225-0557, Vol.78.

Central Statistical Agency (2015). Agricultural Sample Survey 2014/15 (2007 E.C.): Volume II Report on Livestock and Livestock Characteristics (Private Peasant Holdings), Addis Ababa, Ethiopia.

Chala, K., Taye, T. and Kebede, D. (2013). Assessment of Honey Production and Marketing System in Gomma District, South Western Ethiopia: Business and Management Studies, 3(3): 099-107.

Coates, M., Kitchen, R., Kebbell, G. (2011). Financing agricultural value chains in Africa, a synthesis of four country case studies.

Demisew, W. (2016). Beekeeping in Ethiopia: Country Situation, Paper Presented to 5th Api-Expo Africa 2016 Held in Kigali, Rwanda from 21st to 26th September, 2016.

Deutsche Gesellschaftfür GmbH (2007). Value Links Manual: the methodology of value chain promotion, First Edition: Found at internet address http://www.value links.de/manual/ distributor. html.

FAO (2013). FAOSTAT database on agriculture and nutrition: Food and agricultural organization of the United Nations, Rome, Italy. 2009, Available: http://faostat.fao.org/site/569, Accessed 12th Aug. 2015.

FAO. (2010). FAOSTAT database on Agriculture and Nutrition: Food and Organization of the United Nations, Rome, Italy.

Gemechis, L.Yadeta (2015). Honey Production and Marketing in Ethiopian: American Journal of Life Sciences, 3(1): 42-46.

Gereffi, G. and Korzeniewicz, M. (1994). Commodity chains and global capitalism: Westport's.

Gereffi, G., \& Christian, M. (2010). Trade transnational corporations and food consumption: A Global value chain approach. In G. Hawkes, C. Blovins, S.Henson N.Drager.and L, Dube (EDs). Trade, food diet and health: Perspective and policy options (PP91-1100). Oxford, United Kingdom, wiley-Blackell.

Gidey, Y.and Mekonen, T. (2010).Participatory Technology and Constraints Assessment to Improve the Livelihood of Beekeepers in Tigray Region, northern Ethiopia, Momona Ethiopia journal of Science, Vol.2, No.1.

International Livestock Research Institute (2011). Apiculture value chain development in Ethiopia: Ministry of Finance and Economic Development (MoFED). Growth and Transformation Plan (GTP) 2010/11- 2014/15, Working paper, Addis Ababa: Federal Democratic Republic of Ethiopia, Sept. 2010

Kassa, T., Gonche, G. and Amenay, A. (2018). Value Chain Analysis of Honey in Kaffa and Sheka Zones of SNNPR, Ethiopia: International Journal of Research in Agricultural Sciences, Volume 4, Issue 3, ISSN (Online), 2348- 3997. 
Kassa, T., Jema, H. and Bosena, T. (2017). Determinants of honey producer market outlet choice in Chena District, southern Ethiopia: a multivariate probit regression analysis, Agricultural and Food Economics (2017), DOI 10.1186/s40100-017-0090-0.

Mikhail, M., Glenn P. J. \& Richard, R., Barichello (2013). Honey Production in Ethiopia: A Cost-Benefit Analysis of Modern versus Traditional Beekeeping Technologies: Development Discussion Paper, 2013-17.

Ministry of Finance and Economic Development (2010). Growth and Transformation Plan (GTP) 2010/112014/15, Working paper, Addis Ababa, Federal Democratic Republic of Ethiopia, Sept. 2010.

MoA and ILRI (2013). Apiculture value chain vision strategy for Ethiopia: Addis Ababa, Ethiopia: Ministry of Agriculture and International Livestock Research Institute.

Okurut, N., Schoombee, A., Vander Berg, S. (2004). Credit demand and credit rationing in the informal financial sector in Uganda. Paper to the PRU/Tips/Cornell conference on African development and poverty reduction: the Macro-Micro linkage, October 2004.

Porter, M. E. (2004). Competitive advantage: creating and sustaining superior performance (3rd edit,), New York, NY, the free press.

Roduner, D. (2007). Donor intervention in value chain development, working paper.

Tezera, A. B. (2013): Honey market constraints and opportunities in the case of Lasta woreda North Wollo Zone, Amhara regional state, Ethiopia.

United States Agency for International Development (2012). Agricultural Growth Program: Agribusiness and Market Development (AGPAMDe) Project Submitted by ACDI/VOCA to Contracting Officer's, Representative Tewodros Yeshiwork, USAID Ethiopia.

Workneh, A. (2011). Identification and documentation of indigenous knowledge of beekeeping practices in selected districts of Ethiopia: Journal of Agricultural Extension and Rural Development, 3(5): 82-87. 